\title{
Customary Law in An Effort to Implement Social Sanctions in The Midst of The Era of Globalization
}

\author{
Husni Mubaroq ${ }^{1}$ \\ \{Husnimubaroq889@gmail.com ${ }^{1}$ \} \\ Universitas Lampung, Lampung, Indonesia ${ }^{1}$
}

\begin{abstract}
The enactment of customary law actually existed long before the teachings of Islam and Christianity entered Indonesia various interesting things about the effectiveness and how the efforts to apply social sanctions of indigenous law can persist and still exist in the era of globalization at this time that will be the subject of problems in this study. While the purpose of this research is to find out if the social sanctions received by the perpetrator can give a deterrent effect so that the action does not repeat itself. The research method used is to use literature studies as well as delve into various legal sources.
\end{abstract}

Keywords: customary law, social sanctions, effectiveness.

\section{Introduction}

From time to time man is inseparable from the interaction between one individual and another in order to fulfill life in the future. On the basis of this relationship, over time people began to coexist in a region commonly referred to as a group of people [1]In order to achieve a peaceful and safe community life, a rule was established as a guideline for conduct [1]In fact, the various legal developments in Indonesia itself are a source derived from the norms that have existed in society so it can be said that customary law is an unwritten law.

Indonesian has long been known by the international community about the variety of indigenous tribes and languages, so it is no wonder that in each region with a certain indigenous tribe has its own customary laws that must be obeyed by members of its community. It is natural that customary law is considered as an identity of the Indonesian nation, in addition to being considered a rule on the other side of customary law indirectly creating a sense of unity and brotherhood between communities [1]

The history of indigenous law travel is not in Indonesia is not a short matter easy to understand, it is because customary law was born before the country of Indonesia was formed, the reason that many legal experts and history experts are interested in researching the development and how customary law is able to survive until now, Van Vollenhoven once revealed a statement that if one has the desire to add to their insight into the laws that live on this earth because of the diversity that existed in the past to the present, so look for all the rules and history of the law in Indonesia then they will never run out of resources to learn, this subject states the expression that customary law is a characteristic of the indonesian nation [2]Although indigenous peoples in Indonesia have various differences in customs guidelines but the goal remains the same is as a tool in controlling the life that exists in the community and sanctioning in the event of a violation so that customary law is considered as an effective. 
Discussing the existence of customary law then the first question that will arise is how the position of the customary law itself in the national legislation to date, the statement that becomes the answer is that the customary law is certainly clearly included in the Basic Law 1945 namely in Article 18B paragraph (2), Article 28I paragraph (3) and Article 32 paragraph (1) and paragraph (2) of the 1945 Constitution. The description of the contents of these articles is:

1. Article 18B paragraph (2) states that the state recognizes and respects the unity of the indigenous legal community and its traditional rights as long as it is alive and in accordance with the development of the society and principles of the Unitary State of the Republic of Indonesia, which is governed by the law.

2. Article 28I paragraph (3) Cultural identity and the rights of traditional society are respected in accordance with the development of times and civilizations.

3. Article 32 paragraphs (1) and (2), Paragraph 1 (The State advances Indonesia's national culture in the midst of world civilization by guaranteeing people's freedom in maintaining and developing its cultural values), Paragraph 2 (The State respects and maintains the language of the region as a national cultural treasure).

Over time, conflicts have become more frequent as a result of the negative impact of the development of the times that seems to lead the younger generation to do something that violates social norms in society. Thus the impact of this era of globalization is what should make customary law play an important role in society because not all social cases that occur must be resolved into the realm of national law given the cost and time needed [6]Related to the research, this paper will examine several issues including: How are the efforts of indigenous peoples to impose social sanctions in the midst of the current globalization flow? Is customary law effective in imposing social sanctions in the community? This research was conducted in order to find out if the social sanctions imposed by customary law can provide a deterrent effect for perpetrators who violate social norms.

\section{Literatur Review}

When looking at the cultural patterns and customs of Indonesian society should be reformed to the existing legislation undergoing changes, especially the Penal Code which is actually a relic of the Netherlands, indigenous legal experts such as Van Vollenhoven argue that the penal code originating from the windmill country is no longer suitable for good or bad an act that is the benchmark of the Indonesian nation, there are various problems that according to the Penal Code the act can not be criminalized such as the relationship of the blood "incest" [5] Understanding and exploring the values that exist in society is considered very important. As a part of the nation's personality, the existence of customary law must have characteristics and characteristics that correspond to the philosophy and culture of the nation. Sudarto responded that it is not wrong, if to some extent it can be said that the criminal law of a nation can be an indication of the civilization of that nation [5]

It is a pity if a country as large and rich in diversity as the Indonesian nation should forget the identity of customary law which is actually the source of the country's own power [6].

Social sanctions are a series of punishments for members of the public who commit mistakes such as the example described earlier usually the social sanctions that indigenous figures do against the perpetrators of immorality and adultery is by traveling around the 
village or married at the same time. While for other cases such as fights, theft, persecution, the sanction stipulated leads to more damages in the form of material [4]

Most people especially who live in the city may only know about the written law or commonly known as the law and will feel confused if asked about the customary law, in fact the history of the customary law has been around since time immemorial even before the teachings of islam and Christianity entered Indonesia, with the entry of the teachings of islam and Christianity then there is a change in the system of order of the rules due to the mix of two different beliefs. In the era of globalization today the customary law that used to indirectly regulate the order of people's lives is now fading its existence. This is evidenced by the large number of people who prefer to settle their cases into the realm of national law, the emergence of the assumption that customary law is ineffective to solve the problems they face is because customary law is considered too ancient in the middle of the current era of globalization [3]. In every order of public life is inseparable from every legal dynamic regarding the good and bad of an act that happens so that something that will be regulated is considered important. It is not a rare event in any judiciary where a judge will dig in and make values in society in determining a verdict [3]

The impact of the era of globalization instead of affecting people living in urban areas alone but we have expanded into rural areas, in the modern era as it is now making it easier for people to interact with each other and seek information even though the development of the times seems to have a positive impact because facilitating activities in the present does not mean that there are no negative consequences that can be detrimental as we can see is that today there are many crimes committed by teenagers and parents due to from watching porn videos on the Internet, or as another example the rise of underage marriage due to the great curiosity of teenagers dating having free sex. Therefore the application of social sanctions by customary law is necessary for those who have violated the norms in society.

\section{Methodology}

This research uses normative legal research methods, by conducting literature studies as well as documents derived from secondary data sources, namely legal literature related to the problem as well as the purpose of this research.

\section{Discussion}

\subsection{Indigenous Peoples' Efforts to Implement Social Sanctions In the Current Era of Globalization}

The existence of indigenous peoples and the norms of life that seem to have coalesced in it makes the system of customary law order difficult regardless of all the activities of their lives including how to judge a behavior that is done whether it is good or bad, in addition to the development of the times from time to time as if it affects the thinking patterns and ways of view of the younger generation who consider things to be shunned even perceived to be a reasonable act, for example, the nature of polite speaking to an older Person who has ethics must apply polite attitudes and behavior both to young people and moreover to others who are older. For example, when speaking, the person will speak with manners and speak politely and softly. Spoken speech and speech also use intonation that is not high and does not involve 
excessive emotion. Examples for this attitude are numerous and diverse, such as a student towards a teacher, a co-worker with another co-worker, a child to a mother, and so on. But in reality there have been many cases where a student mocks even the courage to persecute his own teacher or for another example there is a child who hit his own birth mother because when asking for money is not given.

The form of indigenous peoples' efforts in resolving conflicts varies greatly following the rules and guidelines of each of their respective regions, many indigenous legal systems that can be reviewed the order and the way they solve the problem, such as the following examples: the first balinese people who have guidelines in the implementation of their own customary law, they are based on awig-awig which is indeed in the regional regulation of Bali Province No. 3 of 2001 has regulated it , As revealed in article 1 number 4 clearly recognized pakraman village where that the village is entitled to its own household [7]According to local regulations awig-awig has a meaning that the regulation is made by pakraman village kerama or banjar pakraman kerama which is used as a guideline tri hita karana based on mawacara village and religious dharma in pakraman village or banjar pakraman respectively [7]

Another example that can be the study material is the indigenous people of Lampung who have Cepalo 12 as the basis of the law of guided and behaved, in accordance with the mention cepalo 12 itself has 12 prohibitions for each member of its community, among others: 1. Forbidden mandang majeu ulun and son mulei ulun jamo view jamo birahi. Hukumano dendo. It is forbidden to look at the wife of a person or a girl with a good view, and the punishment is a fine. 2. Balahkamah or obscene, incitement, mitnah, kabagh buhung. Hukumano dendo. It means that it is forbidden to speak dirty/ obscene, insanity, slander, false news, the punishment is fine. 3. It is forbidden to visit dipok sai more gecak anjak pok mejeng ulun tuho, or ulun sai gham respect. Hukumano dendo. That means it is forbidden to sit in a place higher than the seat of an old person or person we respect. The penalty is a fine. 4 . It is forbidden to appear in front of the ulun ghamik. Hukumano dendo. It is forbidden to show the aurat in front of the public, the penalty is a fine. 5. It is forbidden to nepuk beteng in front of ulun sai lagei meteng.hukumano dendo. It means it is forbidden to pat the stomach in front of a pregnant person, the penalty is a fine. 6 . No pedem tengkurep didawah haghei, in the middle of keppung / tiyuh / ghadeu. It means that it is forbidden to sleep face down in the middle of the day, in the middle of the village or in the middle of the village. The penalty is a fine. 7. Kughuk nuwo ulun baghih liwat belangan is forbidden. This means that it is forbidden to enter others without permission through the back door, the penalty is a fine. 8. It is forbidden to use the room without permission. That means it is forbidden to pass through someone else's room without permission, the penalty is a fine. 9. Bathe is not allowed in sebai baths/ vice versa. This means that it is forbidden to bathe in a women's bath or vice versa. The penalty is a fine. 10. It is forbidden to use ulun baghik tanpomizin pemilikno. It means it is forbidden to take away the rights of others without the permission of the owner, the penalty is a fine. 11. It is forbidden to run mejo ulun, hukumano dikucilken Means it is forbidden to bring /escape the wife of a person, the punishment is excommunicated or expelled. 12. It is forbidden to commit pervert/adultery, hukumano dipatieken. It means that it is forbidden to commit pervert/adultery, the punishment is killed [8]But as many local people do marriage with the migrant community so that gradually the indigenous order system begins to change, in addition many people who start to leave the area out of the island to travel and seek life in a new place.

Customary law is a fairly effective effort made by some communities when a case is considered sufficiently settled in a kinship without having to take the case to court. Van Vollenhoven argues that in order to know about customary law then especially it is necessary 
to know, which areas have the nature and makeup of the federal bodies of law, where the people ruled by the law live daily. If the customary law today continues to live despite decades of obstacles and threats of various forms and if the customary law advances towards its own life, then all that is due to the power of sustaining and the power of life over a national law alliance itself [9] What is often the question among intellectuals is how the position of customary law itself in the national legal system [9]

If traced then it can be known that the position of customary law itself has been stated in Article 18B of the Constitution of the Republic of Indonesia year 1945, as a result of the first amendment of the 1945 Constitution, stating that "The State recognizes and respects the unity of the Indigenous Peoples and their traditional rights as long as it is alive and in accordance with the development of the people and principles of the Unitary State of the Republic of Indonesia, which is governed by the Law." The provisions of Article 18B of the 1945 Constitution are strengthened by the provisions of Article 281 paragraph 3 of the 1945 Constitution that "Cultural identity and traditional society are respected in accordance with the development of times and civilizations". The recognition of indigenous law by the constitution describes that indonesian people are united on various differences both in terms of religion, tribe and culture which from there is symbolized as a single bhineka ika "different but still one" [10]

Efforts to impose social sanctions usually begin by taking mediation measures as a way of progressing towards negotiations by conflicting parties. This settlement is centered by police officers as well as indigenous and religious leaders who do have the right and authority to decide the conflict that occurs, the parties themselves who are trusted as mediators have integrity as well as expertise that is felt to be sufficient to solve the problem [10]Although when viewed based on the development of the era of case resolution efforts using customary legal sanctions is considered antiquated but the choice is considered better done for both parties who are troubled besides strengthening the fraternity rope such efforts can reduce the cost burden and a long time when processed through legal lines.

\subsection{Effectiveness of Customary Law in Providing Social Sanctions In The Community}

Imposed social sanctions by indigenous peoples starting when an act or crime has been committed by a person and judged by the community to have violated existing norms and customs so as to harm and tarnish the good name of the indigenous people' territory, this social sanction is given to the perpetrator in order to cause deterrent effect without having to have a sense of vengeance and drop his or her self-respect. The provision of social sanctions themselves based on the deliberations of indigenous, religious, and local legal officials from the police. For every member of the indigenous community itself is required to comply with the customary law sanctions that apply this is feared given the risk of being excommunicated from the environment in which even some indigenous peoples in Indonesia have strict sanctions on members of the community who violate that is with the punishment of being expelled from the indigenous area. For example, lampung indigenous people who have their own customary law which is all set out in Cepalo 12 in the process of resolving a case by indigenous figures that exist starting from the handling after the case occurs to the stage of making peace accords as well as sanctions given to the perpetrators, in their handling in addition to lampung indigenous figures also involved police officers as mediators of this matter because the police have the right to discretion [8]

If you want to know the effectiveness of indigenous law then there are various supporting aspects that serve to support the real justice of the law. Soerjono Soekanto argues, the theory of legal effectiveness is that effectively not a law is determined by the legal factors 
themselves, law enforcement factors namely the parties that shape or apply the law, the factors of means or facilities that support law enforcement, the socio-economic factors that are the environment in which the law applies or is applied, cultural factors namely as a result of work, copyright, and taste based on human behavior in the association of life. The relationship between the existence of the law and its effectiveness means that certain laws achieve the goal, meaning that the law actually applies and functions in the middle of society[11]

Among the functions of customary law is as a tool of social control and can run properly when there are things that support it. This function is closely related to clear and good legal content material. In addition, the subject that will actualize this law is no less important its role in the implementation of the law as a tool of social control.

Discussing social conflict, customary law as a means of the legal system that has a set of rules or patterns of its own in conflict resolution. That customary law has different characteristics than other legal systems. Conflict is an undeniable and avoidable occurrence in every joint of societal life, this is because conflict is a very fundamental part of the existence of human life itself. The emergence of the conflict must still be faced and resolved by members of the conflicting community not to be avoided, either as a person or a conflicting party, or as a person who will later become the person who mediate to participate in helping to resolve the conflict due to the re-creation of harmony between the warring parties [12]

The discretion itself in its meaning is more towards the moral side than the legal aspect, in addition the authority of the police force itself has been regulated by Law No. 2 of 2002 on the National Police of the Republic of Indonesia, Article 18. Based on the explanation of Article 18 paragraphs 1 and 2 of Law No. 2 of 2002 on the National Police of the Republic of Indonesia it can be understood the Police have the right to act in accordance with its own judgment which means the police have the right to stop or proceed with a complaint or report a criminal offence. The discretionary authority of the police also has a function in the process of solving crimes that are resolved traditionally Lampung because in the peace process between the child perpetrator of the crime and the victim or the victim's family of the crime, the police serve as a mediator or facilitator in the peace of both parties who are troubled and the police also as witnesses of peace from both sides because in making a peace treaty letter in the settlement of child criminal cases that are resolved traditionally Lampung police involvement very important because the peace treaty letter is also held by the police [8]

The effectiveness of the implementation of social sanctions itself can be said both if the people themselves are obedient and obedient to the customary laws that have been passed down a long time ago by their ancestors. Strict social sanctions but do not provide too severe a psychic burden for violators of norm rules in terms of both customary law and national law. The participation of religious beliefs that can help prevent bad deeds from being repeated. As well as the activeness of indigenous and religious leaders in briefing the younger generation not to do deeds outside the prevailing norms and participate in preserving customary law is an action that can be said to be effective so as not to repeat similar events in the future.

\section{Conclusion}

Customary law is a rule and a set of norms that have lived in the community since time immemorial, although the turnaround of the times is growing rapidly but the existence of customary law as an unwritten rule can still be felt in the application of cultured and national life, although the state does not specify clearly about the rules related to customary law but its 
enforcement still exists in the midst of society. Therefore if looking at the enactment of customary law will be more appropriately judged than how sanctions are given more towards having the sense of justice expected by all members of the community. Based on the exposure that has been discussed it can be concluded that customary law as a foundation in the effort to implement social sanctions is still much needed in the midst of the era of globalization. Because customary law is a set of values that arise from the sense of justice that society itself creates. Actually, the public's desire is about the truth not about procedural enforcement.

\section{Advice}

The important position of indigenous law for some people is expected to be able to open a common consciousness so that the identity of the nation that should be preserved is not lost eroded by the changing times, this can be an input for the government to participate in making customary law as a source of renewal of national law later so that the Indonesian nation itself is able to have its own laws that do reflect the identity of the nation.

\section{References}

[1] E. Susylawati, "Eksistensi hukum adat dalam sistem hukum di Indonesia," Al-Ihkam J. Huk. dan Pranata Sos., vol. 4, no. 1, pp. 124-140, 2013.

[2] L. Abubakar, "Revitalisasi hukum adat sebagai sumber hukum dalam membangun sistem hukum Indonesia," J. Din. Huk., vol. 13, no. 2, pp. 319-331, 2013.

[3] M. H. P. Hamzah, "Customary Law Impact in the Development of Indonesia's Criminal Code," J. Crit. Rev., vol. 7, no. 3, pp. 233-236, 2020.

[4] L. O. M. La Ode Raumin and B. Y. Bouto, "BENTUK-BENTUK SANKSI SOSIAL MASYARAKAT TERHADAP PERILAKU MENYIMPANG REMAJA (Studi Di Desa Mabodo Kecamatan Kontunaga Kabupaten Muna),” J. Neo Soc., vol. 3, no. 1, 2018.

[5] R. H. Abdullah, "Urgensi Hukum Adat dalam Pembaharuan Hukum Pidana Nasional," FIAT JUSTISIA J. Ilmu Huk., vol. 9, no. 2, 2015.

[6] I. N. Nurjaya, "Memahami kedudukan dan kapasitas hukum adat dalam politik pembangunan hukum nasional," Perspektif, vol. 16, no. 4, pp. 236-243, 2011.

[7] I. W. G. Wiryawan, K. S. L. P. Perbawa, and I. W. Wiasta, "Hukum Adat Bali di Tengah Modernisasi Pembangunan dan arus Budaya Global," J. Bakti Sar., vol. 4, no. 2, 2015.

[8] H. Pratama, "Penyelesaian Perkara Pidana Anak Secara Adat Lampung Megow Pak Tulang Bawang Dalam Rangka Restorative Justice," FIAT JUSTISIA J. Ilmu Huk., vol. 10, no. 1, 2017.

[9] A. A. S. P. Paraniti, "Eksistensi Masyarakat Adat Bali Dalam Era Globalisasi (Suatu Kajian Filosofis, Yuridis dan Sosiologis)," J. Ilm. Raad Kertha, vol. 1, no. 1, pp. 94-107, 2018.

[10] H. S. Haq and H. Sumanto, "Mengukuhkan Eksistensi Hukum Adat dalam Sistem Hukum Indonesia (Studi terhadap Pengembangan Kelembagaan Mediasi Komunitas)," J. Yust. Merdeka, vol. 2, no. 2, 2017.

[11] A. Surya and S. Suhartini, "Efektivitas Penyelesaian Tindak Pidana Ringan Melalui Lembaga Adat (Sarak Opat)," J. Huk. IUS QUIA IUSTUM, vol. 26, no. 1, pp. 91-112, 2019.

[12] S. Warjiyati, "Eksistensi Hukum Adat Dalam Penyelesaian Konflik Pada Daerah Otonom," Ahkam J. Huk. Islam, vol. 6, no. 2, pp. 389-410, 2018. 